International Journal of Social Sciences and Humanities
Available online at http://sciencescholar.us/journal/index.php/ijssh
Vol. 3 No. 2, August 2019, pages: 176 186
e-ISSN: 2550-7001, p-ISSN: 2550-701X
https://doi.org/10.29332/ijssh.v3n2.311

\title{
Influence Factor of Consumers Interest on Using E-Money
}

CrossMark

\section{Ni Wayan Mentari a, I Nyoman Djinar Setiawina ${ }^{\text {b }}$, I Made Kembar Sri Budhi c , I Wayan Sudirman ${ }^{d}$}

Article history: Received 27 December 2018, Accepted: 30 April 2019, Published: 15 August 2019

\section{Correspondence Author ${ }^{\text {a }}$}

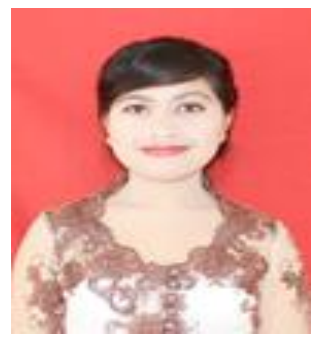

Keywords

attitudes;

benefits;

consumers knowledge;

E-money;

interests;

\begin{abstract}
The objectives of this study was to determine the factors that influence consumer interest in using e-money in Badung and Denpasar City in Bali. This study uses the analysis of SEM structural equations with alternative Partial Least Square (PLS). Consumer attitudes mediate the influence of the relationship between perceived benefits and perceived ease of consumer interest in using e-money, the attitude of consumers in using e-money does not mediate the effect of the relationship between customer knowledge on consumer interest in using e-money. The coefficient of determination R-square for attitude variables is 0.502 , which means that the variable attitude of consumers in using e-money can be explained by the variable perception of benefits, perceived convenience and consumer knowledge by 50.2 percent, or in other words, every variant of consumer attitudes e-money will be explained by the variable perception of benefits, perceived ease and consumers knowledge by 50.2 percent, the rest explained by other variables outside the model by 49.8 percent.
\end{abstract}

e-ISSN: 2550-7001, p-ISSN: 2550-701X ${ }^{\circ}$ Copyright 2019. The Author. SS Journals Published by Universidad Técnica de Manabí. This is an open-access article under the CC BY-SA 4.0 license (https://creativecommons.org/licenses/by-sa/4.0/) All rights reserved.

\section{Contents}

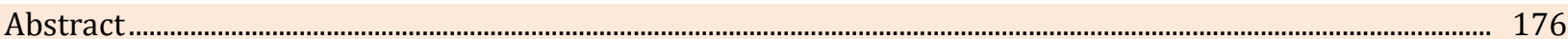

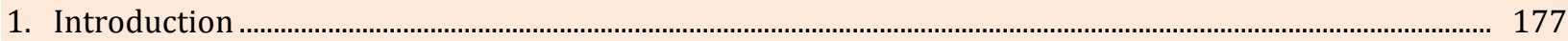

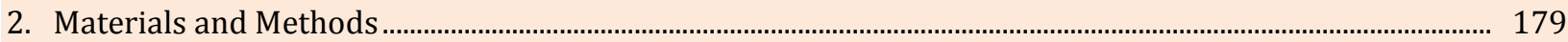

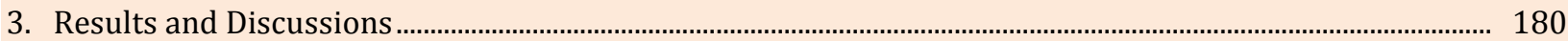

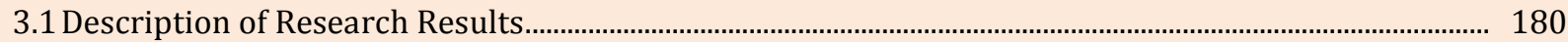

3.2 Discussion of Research Results ............................................................................................................... 182

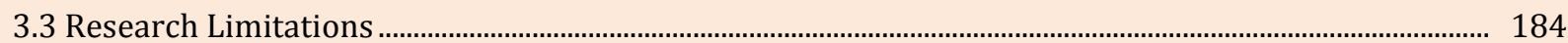

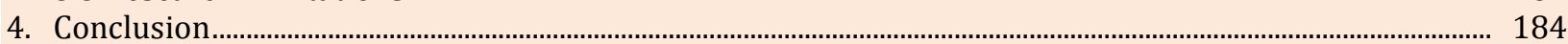

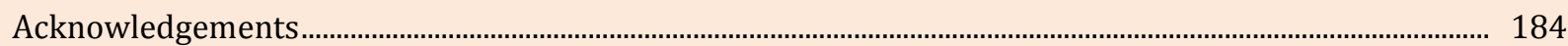

a Udayana University, Denpasar, Indonesia

b Udayana University, Denpasar, Indonesia

c Udayana University, Denpasar, Indonesia

d Udayana University, Denpasar, Indonesia 


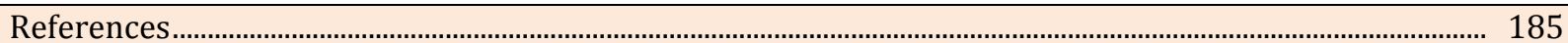

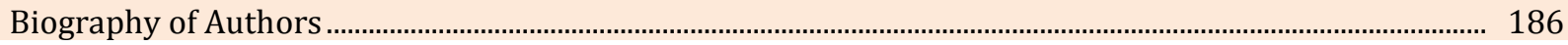

\section{Introduction}

Money was a very large function in every life. As the function of money as a means of payment in economic transactions, money is inseparable from the process of economic transactions. In addition, money can also be said as an important indicator in a country's economy. This is because all economic activities namely production, distribution, and consumption are closely related to money. The role of money in the economy cannot be doubted because money can facilitate the economic activities of the society. In carrying out its duties to regulate and maintain the payment system, Bank Indonesia has a special task that is issuing money as a legal payment instrument in Indonesia which includes printing activities to circulate and regulate the money supply. Along with the rapid development of technology, the pattern of community life and the payment system used in the transaction also experienced changes. Current economic transactions are not only facilitated with cash, but have been penetrated by using non-cash electronic instruments that are more efficient and economical as a result of developments in information technology such as: Card-Based Payment Instruments (APMK) such as credit cards, debit cards, e-money, ATM cards, SKNBI, BI-RTGS systems and finally. As we know that Indonesia is currently entering the era of the digital economy. A digital economy is an economy based on electronic goods and services produced by electronic businesses and traded through electronic commerce (Amin, 2014). The high number of money in circulation, the number of cases of counterfeiting money, and the large operational costs incurred by Bank Indonesia each year in printing, storing, distributing, and destroying money become the background of Bank Indonesia as the Indonesian central bank launched a movement to use non-cash instruments (Less Cash Society). At present, the payment instrument that is most suitable for use in the field of microtransactions is the electronic money system or electronic money (e-money). Electronic money is a relatively new non-cash payment instrument or instrument where e-money is money that is recorded electronically on a card owned by someone.

E-money has several advantages compared to other electronic payment instruments, which prioritize the speed, convenience, and efficiency in conducting transactions. As a relatively new payment instrument in Indonesia, e-money aims to reduce the growth rate of cash usage. The development of e-money is able to create a trend of less-cash society, which is a public behavior that uses non-cash transactions by utilizing the conveniences offered by these transaction tools (Waspada, 2012). Although it is not yet widely used as a primary transaction tool, electronic money has the potential to be a substitute for the cash function as a primary payment instrument. Electronic money holders must have a type of electronic money according to their individual needs because there are many types of electronic money in circulation in Indonesia that offer different facilities and features. Electronic money is a non-cash payment instrument that can make life easier. Unfortunately, there are still many people who do not understand the function and method of using this payment instrument. One of the things that cause the public to still not use electronic money is because people assume that electronic money is the same as other types of cards such as debit or credit cards, even though it is clearly different. Electronic money can be used without using a PIN or other personal identification, while debit cards and credit cards still use the pin input system in transactions. This is clearly different from emoney which is certainly much easier and more practical to use (Agbaeze et al., 2017; Jaminyasa et al., 2017).

In addition, the reason for the unequal number of people who use e-money is because of people's habit of making invoice transactions which cannot be followed up using e-money. In addition, e-money operational support facilities are still very few and limited so that people who have e-money can only use e-money in certain places that provide special e-money reader machines. There are also several variables that influence the attitudes and interests of consumers in using electronic money that the writer adopts are perceptions of benefits, perceptions of convenience and consumers knowledge.

Mentari, N. W., Setiawina, I. N. D., Budhi, I. M. K. S., \& Sudirman, I. W. (2019). Influence factor of consumers interest on using E-money. International Journal of Social Sciences and Humanities, 3(2), 176-186. https://doi.org/10.29332/ijssh.v3n2.311 


\section{Literature Review}

Theory of Technology Acceptance Model (TAM)

Theory of Technology Acceptance Model (TAM) developed by Fred \& Davis (1989), explains the acceptance of technology that will be used by technology users. This theory was adopted from several models that were built to analyze and understand the factors that influence the acceptance of the use of new technologies, including those recorded in various literature and references on research results in the field of information technology are Theory of TAM and Theory of Planned Behavior (TPB). Davis et al., (1989), tried to further develop the TAM model to see the acceptance of the use of computer technology where the acceptance of its use is determined by the attitude of behavior and perceived usefulness (Davis et al., 1989; Korry et al., 2017; Ifeanyichukwu, 2016).

Perceived benefits and perceived ease of use of new technologies affect one's attitude to the use of the technology itself, which in turn will determine whether someone is interested in using technology. As long as the individual feels that technology is useful in his duties, he will be interested in using it regardless of whether the technology is easy or not easy to use. This TAM model shows that when users are presented with new technology, there are a number of variables that influence their decisions about how and when they will use it. Thus, according to Davis (1989), the perception of benefits and ease of being the basic determining factors of technology user acceptance.

\section{Theory of Reasoned Action (TRA)}

This theory was developed by Fishbein \& Ajzen (1975) and compiled using the basic assumption that humans are creatures with the power of reason to decide what behavior will be taken, in a conscious manner and consider all available information. This TRA explains that behavior is carried out because individuals have an interest or desire to do it. Furthermore, Ajzen (1980), suggests that the interest in doing or not doing certain behaviors is influenced by basic determinants, which are related to attitude (attitude toward a behavior). Attitude to behave is defined as a person's positive or negative feelings about performing the desired behavior (Fishbein \& Ajzen, 1975).

\section{Theory of Planned Behavior (TPB)}

This theory is the development of the Theory of Reasoned Action (TRA) by adding a construct (control of perceived behavior) that will influence interest (Ajzen, 1991). The variable included in TPB is the perception of attitude or behavior where the attitude reflects the extent to which the individual has an assessment of agreeing or not agreeing to conduct the behavior. Behavioral control is further broken down into control of belief and perceived power to control one's behavior. Behavioral control Ajzen (1991), shows that attitudes are felt positively related to interests about behavior. An interest in behavior will predict the actual behavior of consumers. Many studies have confirmed that TPB's interest in predicting behavior is more accurate than TRA (Li et al., 2008; Madden et al., 1992; Taylor \& Todd, 1995).

\section{Cognitive, Affective and Conative}

Affection and cognitive structures are part of the consumer behavior model. The cognitive component is the first part of the model that includes the element of cognition (one's belief in the benefits of the product to be used) from someone in the form of knowledge, perception (Schiffman \& Kanuk, 2010; Chitra \& Malarvizhi, 2018).

Cognitively, the knowledge and perceptions that are generated are based on the results of a combination of direct experience of behavioral objects and information related to behavioral objects that have been obtained from various sources. It is the result of this accumulation of knowledge and perception that forms a belief. Then the consumer then believes that the object of behavior has certain attributes and characteristics. The more positive the consumer's trust in a brand, the easier it is for consumers to be able to remember the brand or object of the behavior, also the better the overall cognitive component that is suspected (Hawkins \& Mothersbaugh, 2010).

The affective component is a behavior that involves a person's emotions and feelings over the consequences of the previous component, namely the cognitive component. Emotional results can be positive or negative. In the affective stage, it is also referred to as an overall evaluation of consumers of a brand or 
product (Assael, 1984), because it can be known and measured the level of consumer tendency whether good or not good for a brand or product. While an important part in the concepts of affection and cognitive are knowledge (knowledge) and involvement (involvement) of consumers to the product.

The last component of the Tricomponent Attitude Model is related to the likelihood (likelihood) or tendency (tendency) that someone will do to realize a certain action or behavior towards an object. Hawkins \& Motherbaugh (2010), explained that the behavioral component of this behavior is a person's tendency to respond to certain behaviors towards an object or activity.

\section{Materials and Methods}

Based on empirical studies the hypotheses that can be formulated to provide direction for research analysis:

1) Perceived benefits, perceived convenience, and consumers knowledge have a positive and significant effect on consumer attitudes in using e-money in Badung and Denpasar, Bali Provice.

2) Perceived benefits, perceived ease of use, consumers knowledge, and consumers attitudes in using emoney have a positive and significant effect on consumers interest in using e-money in Badung and Denpasar, Bali Provice.

3) Consumers attitudes in using e-money mediate the effect of the relationship of perception of benefits, perceptions of ease and consumers knowledge of consumer interest in using e-money in Badung and Denpasar, Bali Provice.

The indicators I chose were based on research conducted by previous researchers. The indicators can be explained as follows: 1) Venkatesh \& Davis (2000), share indicators of perceived of benefits, there are : (a) the use of the system can improve individual performance (improves job performance), (b) the use of the system can increase the level of individual productivity (increases productivity), (c) the use of the system is able to increase the effectiveness of individual performance (enhances effectiveness), (d) the use of the system is beneficial to individuals (the system is useful). 2) Perceived ease of use based on Venkatesh \& Davis (2000), divide the dimensions of perceived ease of use into the following: (a) the interaction of individuals with the system is clear and easy to understand (clear and understandable), (b) it doesn't take much effort to interact with the system (does not require a lot of mental effort), (c) easy to use systems, (d) easy to operate the system according to what individuals do (easy to get the system to do what he or she wants to do). 3) For consumer knowledge variables, the indicators used in this study are: (a) product knowledge, (b) knowledge of product transactions, (c) knowing the product risk, (d) knowing the rights and obligations in using the product. 4) For attitude variables which are mediating variables, according to Schiffman \& Kanuk (2008), the characteristics of attitude consist of (a) Receive, (b) Respond, (c) Appreciate and, (d) Responsible. For the variable of consumer interest in the using e-money, according to Ferdinand (2006), Indicators of use interest used in this study are as follows: (a) transactional interest, (b) interest in referrals, (c) referential interest, (d) explorative interest.

This study uses primary data sources namely structured interviews and in-depth interviews directly with the public who use e-money in Badung and Denpasar, Bali Province. The sampling technique was done accidentally on 100 respondents who the authors encountered and who used e-money as a means of payment or transaction. The analytical tool used is descriptive analysis and analysis of SEM structural equations with alternative Partial Least Square (PLS).

The structural equation for path analysis as follows.

$\mathrm{Y} 1=\beta 1 \mathrm{X} 1+\beta 2 \mathrm{X} 2+\beta 3 \mathrm{X} 3+\mu 1$

$\mathrm{Y} 2=\beta 3 \mathrm{X} 1+\beta 4 \mathrm{X} 2+\beta 5 \mathrm{X} 3+\beta 6 \mathrm{Y} 1+\mu 2$

Where, $\mathrm{X} 1$ = Perception of Benefits, $\mathrm{X} 2=$ Perception of Ease, $\mathrm{X} 3=$ Consumers Knowledge, Y1 = Consumers Attitude, $Y 2=$ Consumer Interest, $\beta 1, \beta 2, \beta 3, \beta 4, \beta 5, \beta 6=$ path coefficient, $\mu 1, \mu 2=$ inner residual (structural error). The research model can be seen in the following figure 1 :

Mentari, N. W., Setiawina, I. N. D., Budhi, I. M. K. S., \& Sudirman, I. W. (2019). Influence factor of consumers interest on using E-money. International Journal of Social Sciences and Humanities, 3(2), 176-186. https://doi.org/10.29332/ijssh.v3n2.311 


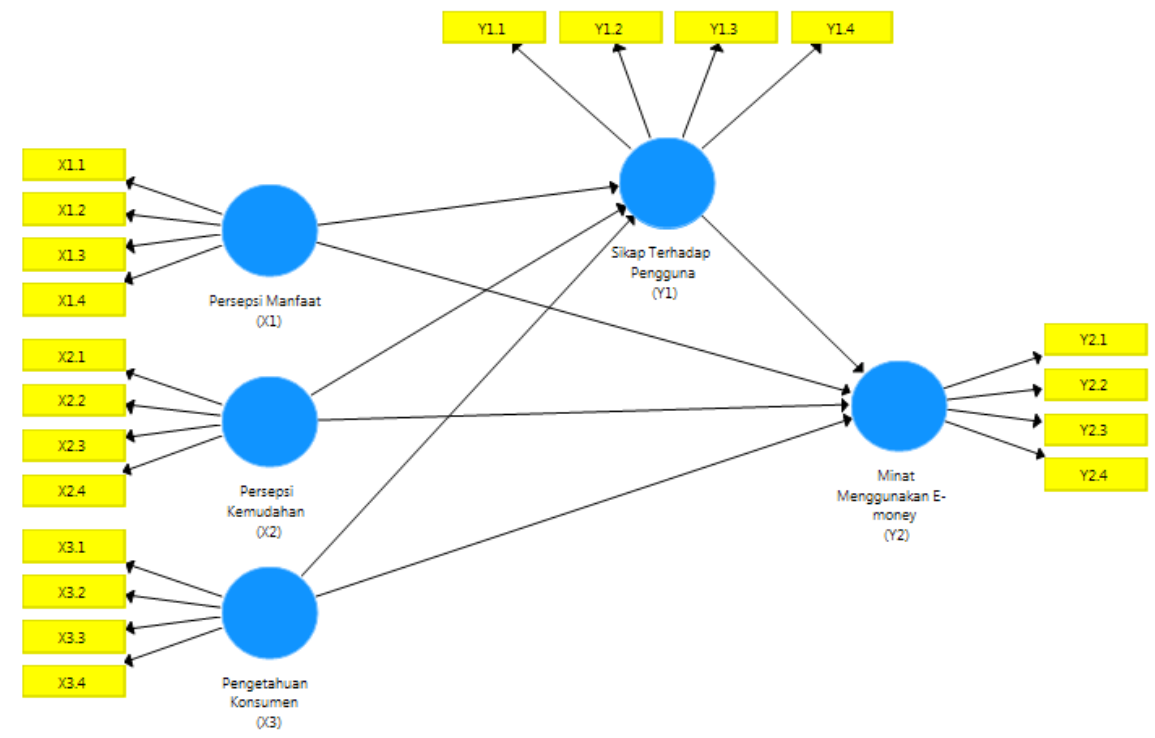

Figure 1. Research model

To see how big the role of a variable in mediating is used the Sobel test ( $\mathrm{Z}$ test) with the following formula:

$$
z=\frac{a b}{\sqrt{b^{2} S_{a}^{2}+a^{2} S_{b}^{2}}}
$$

Where: $a=$ coefficient of regression of independent variable to regression variable, $b=$ regression coefficient of mediation variable to the dependent variable, $S E_{a}=$ standard error of estimation from the effect of the independent variable on the mediating variable, $S E_{b}=$ standard error of estimation from the effect of mediating variables on the dependent variable.

\section{Results and Discussions}

\subsection{Description of Research Results}

E-money is a payment instrument that is still relatively new and people are starting to adapt in its use. Before discussing further the research data that has done, will be explained for a little about the process of the formation of e-money. E-money is a stored value or prepaid product in which a certain amount of money is stored in an electronic media owned by someone, whose value will decrease when used for payment of various types of transactions (multi-purpose). Broadly speaking, the factors that influence the use of non-cash payment instruments are as follows: a) the needs of the community, b) the availability of instruments that are easy, safe, fast and efficient, c) the number of outlets or market players that accept payment instruments the non-cash.

Choosing the right payment segment also affects the success of the use of non-cash payment instruments by the wider community. Specifically for e-money, based on e-money characteristics and e-money development experience in various countries, it can be said that the initial development of e-money is generally intended for payment segments that have the following criteria: a) small value transactions (micropayments up to retail payments), b) the frequency of their use is relatively frequent; and c) mass.

The respondents I met when conducting field research were 100 respondents who were dominated by male respondents, 88 percent and the remaining 12 percent female respondents. When viewed from age, age range 36-45 years old respondents with a total of 35 people or 35 percent, then followed by the age range of 26-35 years as many as 31 people or 31 percent. As many as 23 people or 23 percent in the range of 18-25 
years, a range of 46-55 years as many as 10 people or 10 percent and the remaining 1 person or 1 percent with a range of 56-65 years. These conditions indicate that respondents with a majority of ages 26-35 and 3645 years who are productive ages who are working and are the backbone of the family that most use e-money as a means of non-cash payment transactions.

When viewed by type of work, as much as 64 percent or 64 people dominate the use of e-money with work as private employees, 15 percent work as entrepreneurs, 14 percent others. Professionals as Civil Servants use e-money by 5 percent of 100 study sample, and only 2 percent of respondents using e-money who work as students or college students. Based on research data, it shows that the job as a private employee is the most work carried out by respondents who use e-money as many as 64 people or 64 percent. They are workers who need e-money as a non-cash payment instrument required by the government or in other words they are toll road users in Bali who if they want to use the toll road are required to have e-money. For the status of respondents, as many as 71 people or 71 percent of respondents were married while 29 people or 29 percent were single.

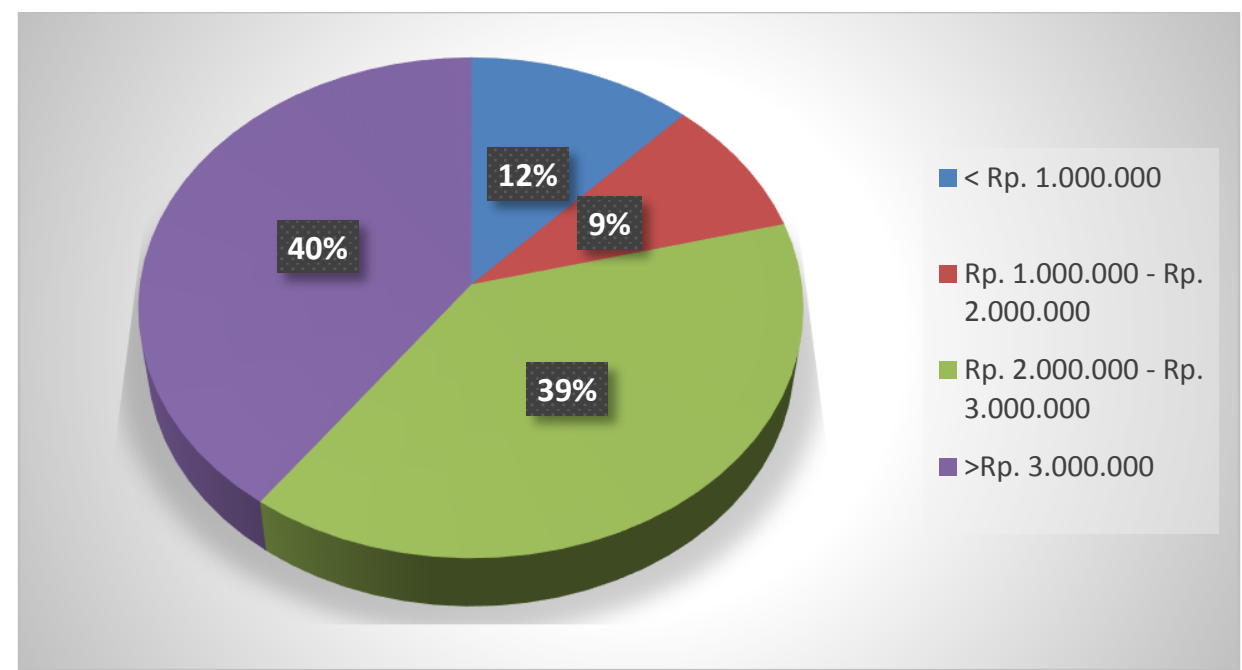

Figure 2. Characteristics of respondents by their income

If seen based on the amount of income, it can be seen that what dominates the use of e-money is the community or respondents who earn more than Rp. 3,000,000 40 or 40 percent. Respondents who earn Rp. 2,000,000 - Rp. 3,000,000 ranked second using e-money as many as 39 people or 39 percent. Respondents who earn Rp. $1,000,000-2,000,000$ are 9 people or 9 percent, then the remaining 12 people or 12 percent earn less than Rp. 1,000,000. People who earn more than Rp. 2,000,000 and above Rp. 3,000,000 use e-money the most because in the research area there are in Denpasar and Badung having the Minimum Wage Employee Criteria above Rp. 2,000,000. This is supported by the condition of the Region which is very adequated with Denpasar as the industrial center and Badung as Bali's tourism center with a fairly high financial transaction cycle. In addition, respondents who use e-money the most are private employees who certainly earn more than the regional minimum wage with regions with high economic turnover. Here below, we present the types of e-money products used by respondents.

Mentari, N. W., Setiawina, I. N. D., Budhi, I. M. K. S., \& Sudirman, I. W. (2019). Influence factor of consumers interest on using E-money. International Journal of Social Sciences and Humanities, 3(2), 176-186. https://doi.org/10.29332/ijssh.v3n2.311 


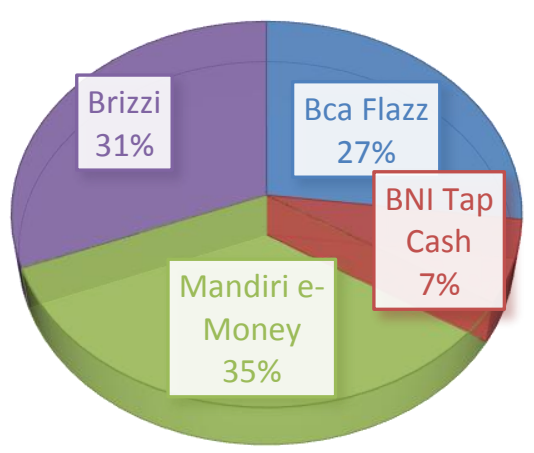

Figure 3. Types of e-money products used

For e-money products, the most frequently used products are e-money products from Bank Mandiri, namely Mandiri e-money by 35 percent of the total respondents, then the second type of product most often used is Brizzi by 31 percent, then e-money products BCA Flazz is 27 percent and the last is BNI Tap Cash by 7 percent. During the research and based on the sources obtained by the author, the customer chooses to use e-money products whose facilities are supported by the relevant financial institution. Mandiri e-money products have collaborated with well-known minimarkets in Indonesia by helping to provide reader machines and e-money top-up places. For the frequency of using e-money, the highest frequency of people using e-money is around 34 times a week, which is 24 percent. As many as 30 percents of people who only use e-money 1-2 times a week, e-money users more than 6 times a week are 27 percent and users are 4-6 times a week the lowest is 9 percent. The frequency or level of frequency of someone using e-money actually depends on the need for the use of the product.

\subsection{Discussion of Research Results}

Discussion relating to the results of research data processing and hypothesis testing and further analysis of the results of the research. The results of the study will be reviewed descriptively and exploratively so that the meaning and reasons why research results like this can be known. Furthermore, the results of the study are also associated with theories and results of previous studies. According to the results of the calculation of the path coefficient and T-Statistics the effect of perception of benefits on consumer attitudes in using e-money obtained a positive path coefficient of 0.337 and T-Statistics 2.707 which means that the perception of benefits has a positive effect on consumer attitudes in using e-money and the effect is significantly seen from p-value $0.007<0.005$ or in other words the perception of benefits has a positive and significant effect on consumer attitudes in using e-money. Irmadhani \& Nugroho in Wijayanti (2017), states that the perception of benefits is related to the productivity and effectiveness of the system from the overall perceived usefulness or benefits in order to improve the performance of the users of the system. When users of electronic money feel that there are many benefits that can be obtained from using electronic money such as providing convenience, speed, and practicality in conducting various transactions, the community feels the benefits of using electronic money, thereby significantly increasing attitudes in using electronic money.

The effect of perception of ease on consumers attitudes to using e-money obtained a path coefficient of 0.383 and T-Statistics 2.952 or p-value $0.003<0.05$ where it means that perceptions of ease and positive influence on consumer attitudes in using e-money. The effect of perceived ease can be explained that if a person feels or believes that the information technology system is very easy, then he will use it and vice versa if the user believes if the system is difficult to use then the user is reluctant to use (Davis, 1989), in the context of this study, the users of e-money considers that transactions made using e-money in places that require using e-money such as tolls, as well as in mini markets that provide merchants to process transactions using e-money are very easy, thus encouraging attitudes in using e-money.

The effect of consumers knowledge on consumer attitudes in using e-money obtained path coefficient of positive 0.063 and T-Statistics 0.692 or p-value $0.489>0.05$, it means that consumer knowledge has no significant effect on consumer attitudes in using e-money. This research is an exploratory study about the 
effect of consumers knowledge on attitudes in using e-money, the authors see that during research on respondents, respondents' knowledge and their understanding is still minimal about e-money where there are some respondents who are forced to use products without knowing more in detail about the e-money. In addition, government or e-money issuing socialization institutions are still lacking so that there are still many people who have not used e-money.

The effect of perception of benefits on consumer interest in using e-money obtained by the variable perception of the benefits of use has a significance value of $0.101>0.05$. This means that the hypothesis is rejected, which means that the perception of benefits does not significantly influence consumer interest in using e-money in Badung and Denpasar in Bali. As for some things that cause the perception of benefits does not significantly influence interest in using e-money is due to several things, namely as follows: a) e-money cards can indeed be used as a means of payment at merchants in addition to using cash, but merchants who want to accept payments using e-money cards a little as well as payments using a debit card. Merchants prefer to accept payments using credit cards because they can get fees from customers when a transaction occurs, whereas when using e-money, do not get fees, b) the use of e-money as a payment instrument is still not considered to have good benefits because if the system it is easy to use or not easy to use, it is due to the lack of promotion of benefits obtained from transactions using e-money. Besides that, when viewed from the usevalue of e-money that cannot be used for small traders who have so far still used cash or cash as their payment system, it is also a factor causing the lack of people who use e-money.

The effect of perceived convenience on consumer interest in using e-money obtained path coefficient of negative 0.079 and T-Statistics 0.551 . This means that perceptions of convenience have a negative effect on consumer interest in using e-money and this effect is not significant with T-Statistics smaller than 1.65, or in other words, perceptions of ease have a negative and not significant effect on consumer interest in using emoney -money. As for some things that can cause a lack of public interest in using e-money even though some facilities have been provided are as follows: a) supporting facilities for e-money procurement are still lacking, namely in the form of limited merchants or reader machines, b) reader machines often have errors when the transaction process and when consumers top-up, so precisely when transacting using e-money can take quite a long time because they have to wait for the machine to return to normal, c) if the transaction uses certain emoney, it must be at outlets that have reader machines that have in accordance with the e-money brand. Like Brizi e-money cards, transactions can only be made if there is a reader machine from the card-issuing institution, namely BRI. In addition, with the behavior or culture of people who often transact in the bill, the people's interest to use e-money is still low. E-Money is also pre-paid where the money we have is stored on the e-money card and the balance will be reduced if we use it to process transactions so we must first save money on the card so that e-money can be used.

The influence of consumer knowledge on consumer interest in using e-money obtained a positive path coefficient of 0.269 and T-Statistics 2.609. This means that consumer knowledge has a positive effect on consumer interest in using e-money and that influence is significant with T-Statistics greater than 1.65, or in other words consumer knowledge has a positive and significant effect on consumer interest in using e-money. Product knowledge is product knowledge that's owned by consumers about the product or service to be consumed.

The influence of attitudes on consumer interest in using e-money obtained p-value $0,000<0.005$. This means that attitude has a positive and significant effect on consumer interest in using e-money in Badung and Denpasar in Bali. With the feeling of enjoyment and happiness owned by the respondents, it will affect the interest in behavior to use the internet. Consumers tend to be positive or negative towards the procurement of a product. They will accept or not the product for daily purposes. In this case, most respondents are positive or accept the existence of e-money as a means of payment so that they are interested in using e-money as one of the means of payment in transactions.

Based on the results of the intervening test, the results obtained that the intervening variable mediation consumers attitude has a significant role in the influence of perception of benefit on consumers interest to using e-money which can be seen from the $\mathrm{z}$ count value of $2.325>1.65$. The mediating variable of consumers attitude mediates the influence of perceived ease of consumers interest in using e-money in Badung and Denpasar, Bali that can be seen from the calculation of $\mathrm{z}$ value of $2.466>1.65$. The effect of mediating variables consumers attitude does not mediate the effect of consumer knowledge on consumers interest to using emoney in Badung and Denpasar, Bali. This can be seen from the calculated $\mathrm{z}$ value of $0.707<1.65$.

Mentari, N. W., Setiawina, I. N. D., Budhi, I. M. K. S., \& Sudirman, I. W. (2019). Influence factor of consumers interest on using E-money. International Journal of Social Sciences and Humanities, 3(2), 176-186. https://doi.org/10.29332/ijssh.v3n2.311 


\subsection{Research Limitations}

This study only used samples in two of the nine regions in Bali, there are Badung and Denpasar City. This is due to the limited time, place and material. According to researchers, this does not yet represent the overall perception of the public who use e-money widely, because there are still many other areas in the community who use e-money that is interesting to study. Therefore, the next researcher should try to expand the sample of research in addition to the two districts or cities that the author has used. Differences in results from previous studies are influenced by differences in research models, differences in the use of variables and differences in research sites.

\section{Conclusion}

The purpose of this study is to analyze the factors that influence consumer interest in using e-money in Badung and Denpasar, Bali. The results obtained indicate that the perception of benefits and perceptions of ease have a positive and significant effect on consumer attitudes in using e-money, while consumer knowledge has no significant effect on consumer attitudes in using e-money in Badung and Denpasar, Bali. Perception of benefits does not significantly influence consumer interest in using e-money, perceived ease of use has a negative and insignificant effect on consumer interest in using e-money, consumer knowledge and attitudes have a positive and significant effect on consumer interest in using e-money in Badung and Denpasar, Bali. Consumer attitudes in using e-money mediate the full influence of the relationship between perceived of benefits and perceived ease of consumer interest in using e-money, whereas consumer attitudes in using e-money do not mediate the effect of the relationship between consumer knowledge on consumer interest in using e-money in Badung and Denpasar, Bali.

Based on research in the field that the author has done, as for the advice that can be given is: 1) the bank should be able to further examine the factors that influence one's interest in using e-money products, given that e-money users have increased every year, but its use cannot be maximized because the facilities or supporting facilities for e-money procurement are still very minimal and often suffer damage. 2) In order for e-money procurement to be effective, it is better for the government to add e-money procurement facilities and supporting facilities such as increasing the provision of merchants to outlets that provide payment transactions using e-money so that the limitations of e-money support facilities or facilities can be overcome. One way is through the link process, namely, all types of e-money cards can be used in one reader machine (link). 3) The public understanding of the use of e-money should also be improved by supporting the dissemination of e-money and expanding the use of electronic money, for example, it can be channeled on television so that people are more familiar with electronic money, its benefits, and uses. In addition to socialization, the use of e-money should be expanded, such as for example e-money has been used to pay tolls, it is better if the use of e-money can also be used for parking payments and expanding the use of e-money, such as for theaters, refilling petrol, and so on. Because in addition to the existence of some benefits, convenience, and knowledge, the consumers need to use a product (e-money) can also increase the volume of society in using e-money. In addition, the security of e-money also needs to be considered by financial institutions as authorizations.

\section{Acknowledgments}

The authors would like to thank the editor of IJSSH for their valuable time, support and advice in completing the current study. 
References

Agbaeze, K. E., Monyei, E. F., \& Agu, O. A. (2017). Impact of talent management strategies on organizational performance in selected deposit money banks in Lagos State, Nigeria. International Research Journal of Management, IT and Social Sciences, 4(2), 135-151.

Ajzen, I. (1991). The theory of planned behavior. Organizational behavior and human decision processes, 50(2), 179-211. https://doi.org/10.1016/0749-5978(91)90020-T

Amin, S. (2014). Capitalism in the age of globalization: The management of contemporary society. Zed Books Ltd..

Assael, H. (1984). Consumer behavior and marketing action. Kent Pub. Co..

Chitra, S., \& Malarvizhi, M. (2018). A study on Consumer Reaction on Passenger Car Tyre Selection in Theni. International Research Journal of Management, IT and Social Sciences, 5(2), 64-68.

Davis, F. D. (1989). Perceived usefulness, perceived ease of use, and user acceptance of information technology. MIS quarterly, 319-340. https://doi.org/10.2307/249008

Davis, F. D., Bagozzi, R. P., \& Warshaw, P. R. (1989). User acceptance of computer technology: a comparison of two theoretical models. Management science, 35(8), 982-1003. https://doi.org/10.1287/mnsc.35.8.982

Davis, F. D., Bagozzi, R. P., \& Warshaw, P. R. (1989). User acceptance of computer technology: a comparison of two theoretical models. Management science, 35(8), 982-1003. https://doi.org/10.1287/mnsc.35.8.982

Ferdinand, A. (2006). Metode penelitian manajemen.

Fishbein, M., \& Ajzen, I. (1975). Intention and Behavior: An introduction to theory and research.

Fishbein, M., \& Ajzen, I. (1980). Predicting and understanding consumer behavior: Attitude-behavior correspondence. Understanding attitudes and predicting social behavior, 148-172.

Hawkins, D. I., Mothersbaugh, D. L., \& Best, R. J. (2010). Consumer behavior. NY: McGraw-Hill.

Ifeanyichukwu, C. D. (2016). Effect of celebrity endorsements on consumers purchase decision in Nigeria. International Research Journal of Management, IT and Social Sciences, 3(9), 120-128.

Irmadhani, I. (2012). Pengaruh Persepsi Kebermanfaatan, Persepsi Kemudahan Penggunaan dan Computer Self Efficacy, terhadap Penggunaan Online Banking pada Mahasiswa S1 Fakultas Ekonomi Universitas Negeri Yogyakarta. Kajian Pendidikan Akuntansi Indonesia, 1(3).

Jaminyasa, I. M., Pulawan, I. M., Martadiani, A. M., \& Amerta, I. M. S. (2017). The marketing mix affect on the consumer buying decision (case study of sausage products at PT. Aroma Denpasar). International Journal of Social Sciences and Humanities, 1(2), 65-74. https://doi.org/10.29332/ijssh.v1n2.44

Korry, P. D. P., Yulianti, N. M. D. R., \& Yunita, P. I. (2017). Increase the attractiveness of local fruits to buying intention of hedonic consumers in bali. International Research Journal of Management, IT and Social Sciences, 4(6), 10-16.

Li, M., \& Vitányi, P. (2008). An introduction to Kolmogorov complexity and its applications (Vol. 3). New York: Springer.

Madden, T. J., Ellen, P. S., \& Ajzen, I. (1992). A comparison of the theory of planned behavior and the theory of reasoned action. Personality and social psychology Bulletin, 18(1), 3-9. https://doi.org/10.1177\%2F0146167292181001

Schiffman, L. G., Kanuk, L. L., \& Wisenblit, J. (2010). Consumer Behaviour: Global Edition.

Schiffman, L., \& Kanuk, L. L. (2008). Perilaku konsumen. Jakarta: Indeks.

Taylor, S., \& Todd, P. A. (1995). Understanding information technology usage: A test of competing models. Information systems research, 6(2), 144-176. https://doi.org/10.1287/isre.6.2.144

Venkatesh, V., \& Davis, F. D. (2000). A theoretical extension of the technology acceptance model: Four longitudinal field studies. Management $\quad$ science, 46(2), $186-204$. https://doi.org/10.1287/mnsc.46.2.186.11926

Waspada, I. (2012). Percepatan Adopsi Sistem Transaksi Teknologi Informasi untuk Meningkatkan Aksesibilitas Layanan Jasa Perbankan. Jurnal Keuangan dan Perbankan, 16(1).

Wijayanti, T. P., Pinem, A. A., Handayani, P. W., \& Ruldeviyani, Y. (2017). Knowledge management system design of indonesian general district hospital. Journal of Engineering and Applied Sciences, 12(4), 808-813.

Mentari, N. W., Setiawina, I. N. D., Budhi, I. M. K. S., \& Sudirman, I. W. (2019). Influence factor of consumers interest on using E-money. International Journal of Social Sciences and Humanities, 3(2), 176-186. https://doi.org/10.29332/ijssh.v3n2.311 


\section{Biography of Authors}

\begin{tabular}{|c|c|}
\hline & $\begin{array}{l}\text { Ni Wayan Mentari, S.E. was born on September } 4^{\text {th }}, 1993 \text { in Gianyar. She is a } \\
\text { college student on the Master of Economic Science in the faculty of economics } \\
\text { and business, Universitas Udayana. She lives at Puakan, Taro Village, Tegallalang, } \\
\text { Gianyar-Bali. She graduated her bachelor degree in Faculty of Economics and } \\
\text { Business, Udayana University, Denpasar in } 2016 . \\
\text { Email: niwayanmentari@gmail.com }\end{array}$ \\
\hline & $\begin{array}{l}\text { Prof. Dr. Nyoman Djinar Setiawina, SE., MS was born on July } 30^{\text {th }}, 1953 \text { in Nusa } \\
\text { Penida. He is a lecturer in the faculty of economics and business, Udayana } \\
\text { University from } 1983 \text { to present. He lives at Jl. Pulau Batam II No. 14 Denpasar, Bali. He } \\
\text { graduated his bachelor degree in Economics Faculty, Udayana University in } 1979 \\
\text { with B.Sc. and Drs. in 1982. He finished his Master degree in Population Studies at } \\
\text { Gadjah Mada University, Yogyakarta in 1990. He completed his doctorate on Fiscal } \\
\text { and Monetary Concentration at Airlangga University in } 2001 . \\
\text { Email: djinarsw12@gmail.com }\end{array}$ \\
\hline & $\begin{array}{l}\text { Prof. Dr. Drs. Made Kembar Sri Budhi, M.P. was born on February } 12^{\text {th }}, 1958 \text { in } \\
\text { Tajun, Buleleng. He is a lecturer in the faculty of economics and business, } \\
\text { Udayana University from } 1986 \text { to present. He lives at Jalan Kerta Bedulu IV No. } 1 \\
\text { Denpasar, Bali. He graduated his bachelor degree in Economics Faculty, Udayana } \\
\text { University in 1984. He finished his Master degree in Agricultural Socio-Economic at } \\
\text { Gadjah Mada University in 1993. He completed his doctorate in Economic } \\
\text { development at Airlangga University in 2007. } \\
\text { Email: kacung_dobel@yahoo.com }\end{array}$ \\
\hline & $\begin{array}{l}\text { Prof. Dr. I Wayan Sudirman, S.E., S.U was born on May } 10^{\text {th }}, 1950 \text { in Denpasar. He } \\
\text { is a lecturer in the faculty of economics and business, Udayana University from } \\
1978 \text { to present. He lives at Jln. Abianbase } 27 \text { Kelurahan Abianbase Kecamatan } \\
\text { Mengwi Badung Bali, Bali. He graduated his bachelor degree in Economics Faculty, } \\
\text { Udayana University in management study. He finished his Master degree on } \\
\text { Monetary Economy at Gadjah Mada University, and he completed his doctorate of } \\
\text { financial monetary and banking economics at Gadjah Mada University. } \\
\text { Email: wsudirman@unud.ac.id }\end{array}$ \\
\hline
\end{tabular}

